\title{
PETER EISENMAN AND THE POSSIBILITY OF AN AESTHETIC FORMALISM
}

Formal considerations constitute the core aspect of Peter Eisenman's work. Arguably, they are the only consistent theme of his work, and are based on the concept that architecture is a mediation between the embodied internal world of human beings and the external physical world which we inhabit. Eisenman thus gives form a 'conceptual' rather than perceptual basis, whereby universal formal relationships are more important than sensual aspects. This leaves architecture as a syntactic operation based on reason and logic, with apparent formal relationships as is its main justification. The understanding and development of an inherent formal language becomes the main goal in such an approach, and meaning is disregarded in its extrinsic character with a reference to social, historical or other representational traits.

In this paper I am discussing Eisenman's views on architectural formalism through the scope of aesthetics. Since he disregarded aesthetic considerations throughout his career, especially beauty, it is fruitful to explore and examine his stance on the properties of architecture as a way to justify his claims of formal primacy. I am basing my analysis on Nick Zangwill's formalist theories, and thus giving primacy to the formal-spatial properties of the architectural object as being judged by the human subject. This could bring back the discussions of formalist aesthetics to architectural theory and makes the judgment of architectural 


\section{INTRODUCTION}

When thinking about the intellectual aspect of architectural design, we tend to give prominence to explicitly stated ideas and concepts about the origin of the design. These ideas are expected to provide justification for formal choices and give the architect a much-needed guidance in a design process. Nevertheless, we are left with a question pertaining to the basis for these ideas. This concerns the well-established dilemma in both the history of architectural theory and the history of aesthetics, which deals with the question of whether formal-spatial considerations could always be reduced to the concepts or meanings associated with these shapes, or if it is possible that formal-spatial properties are perceived independently. Obviously, this paper cannot resolve this dilemma of formalist and conceptualist aesthetics, but I intend to discuss the division based on Peter Eisenman's example, one of the most prominent architects and theorist of the last 60 years. I do not intend to give a full record of his intentions or sources, but to identify possible theoretical dilemmas that relate to aesthetics with the basis in, but not limited to his early formalist work.

Arguably, Eisenman attempted to suppress the role of aesthetics throughout his career. ${ }^{1}$ In his search for the inherent capabilities of architecture, aesthetics has been deemed extrinsic and thus insignificant to give architecture its value. This position raises numerous questions regarding both the intrinsic properties of architecture and the following role of the subject in assessing these properties. I will start by introducing a number of definitions necessary in order to formulate questions that should provide a substantial foundation for further discussion on the problems of Eisenman's work.

Even if there are many approaches to the concept of the aesthetic, like the aesthetic object, the aesthetic value, the aesthetic judgment, or the aesthetic experience, this paper takes the position that it concerns some kind of subjective sensation with a subsequent response. It may seem uncontroversial to say that architects have to make aesthetic judgements in order to make decisions in a design process, but what these judgements rely on is less certain. This is where the division between intrinsic and extrinsic properties takes place, and the question is thus: is aesthetic value based on properties that exist in the perceived object, or is it based on properties that exist outside of that object? In architecture, this relates to either the visually perceivable formal-spatial properties or to conceptually understood properties concerning representations of function, history, culture, and so on. Eisenman's work is not so easily classified when it comes to this dilemma. His complex and ever-changing theories make it possible to see his position in both the formalist and the conceptualist camps. 
I will nevertheless suggest a possible formalist position based on his stand on the relationship between the formal properties of an architectural object and subjective judgements. I will lay out a brief definition and classification of aesthetic judgements and varying properties these judgements rely on in order to further discuss Eisenman's position. In the following paragraphs I will therefore give a short summary of Nick Zangwill's (philosopher) position on aesthetic formalism before I return to Eisenman.

\section{PETER EISENMAN AND THE POSSIBILITY OF AN AESTHETIC FORMALISM}

\section{Aesthetic Judgments and Aesthetic Properties}

I am basing my analysis on Zangwill's views that aesthetic judgements begin with the judgement of aesthetic merit or demerit. This is a value judgement of beauty or ugliness and is thus called verdictive. ${ }^{2}$ Zangwill interprets Immanuel Kant by claiming that these judgements are subjective and aim to produce a pleasing or displeasing response in the subject. ${ }^{3}$ The function of the verdictive judgement is thus to determine whether something has aesthetic value, which makes it the fundamental aesthetic judgment in a hierarchy of judgements that Zangwill describes. The next layer is the substantive judgement, where 'substantive properties determine value or disvalue'. ${ }^{4}$ These judgements are characterised by our ability to recognise these properties, such as the dainty, dumpy, elegant, graceful or garish. In other words, substantive judgments are a way to describe how and why things are attributed aesthetic merit through aesthetic properties and are subordinate to the fundamental judgement of aesthetic value. $^{5}$

It is important to note that for Zangwill, representational judgements fall short of the previously mentioned category of aesthetic judgements (verdictive and substantive). Since a representational judgement implies recognising something in an object, it is not necessary for us to have an aesthetic response from making this judgement, even if this may be the case. ${ }^{6}$

This brings us to the relationship between aesthetic judgements and aesthetic properties, and subsequently to the relationship between aesthetic and nonaesthetic properties, for instance, between beauty and a certain arrangement of shapes and colours. Zangwill holds that 'what we know as part of understanding aesthetic concepts is that if a thing has an aesthetic property, then it has some non-aesthetic property which is responsible for it'. ${ }^{7}$ This means that aesthetic 
properties depend on non-aesthetic properties, which in turn gets us to the proposition that there may be a direct link between the physical world of objects, and the perceiving subject making judgements based on the formal properties of these objects. ${ }^{8}$ There is also an opportunity for this judgement to be independent of representational properties based on what we know of certain conventions and extrinsic signification. ${ }^{9}$ This has significant implications for arguments on formal decisions in architecture and could clarify the problem of which properties an architectural object should have in order to hold aesthetic value.

\section{Eisenman's Formalism}

As mentioned above, Eisenman is not interested in the aesthetic properties of architecture, but throughout his career he made several analyses on the nonaesthetic formal properties. They were not meant to generate a subjective aesthetic judgement or any certain meaning, but as an internal mechanism generating a self-referential architecture in its pure form. ${ }^{10}$ In his constant arguments against the meaning of architecture, Eisenman has obviously been opposing the representational properties such as the social, historical or functional meanings. ${ }^{11}$ At the same time he has equated any aesthetic judgement with the same kind of meaning, and thus denied a verdictive aesthetic judgement based on formal non-aesthetic properties. Obviously, this formulated resistance to the meaning of architecture leaves space for the possibility of a formalist aesthetic approach, especially since it presupposes a direct link between the non-aesthetic formal properties of an architectural object and the subject's aesthetic judgement.

In his 1963 dissertation, The Formal Basis of Modern Architecture, Eisenman tried to establish a general theory of form with universal validity, independent of traditional conceptualist traits, such as historical considerations, moral or humanistic grounds. Formal issues were resolved with the use of a grammar of architectural elements based on a syntactic logic where all shapes were variations of a generic antecedent. In this way architecture was evaluated on terms related to language, with syntax being a basic set of rules providing the direction for a distortion of the generic form (defined as volume, surface, mass and movement). ${ }^{12}$ The division into generic and specific forms, where 'form in its generic state provides the conceptual reference for all physical manifestations of specific form', ${ }^{13}$ was meant to establish a universal formal language independent of style. Consequently, form and space were structured in order to produce certain relationships which were inherent in the forms themselves. $^{14}$ 
Eisenman wanted to avoid the semantics, and thus to avoid any value judgement based on representational properties or social or historical meanings outside of architecture. By giving prominence to intrinsic formal relationships, architecture could be regarded as neutral and objective, ${ }^{15}$ and its true representation was through axonometric drawings and diagrams which provided this non-subjective neutral point of view. In Eisenman's cardboard houses of the 1970s, the process of the formal development of the projects as represented in these drawings, were far more important than the final buildings themselves. ${ }^{16}$ Both the diagram and the axonometric was viewed as 'the mediation between a palpable object, the real building and architecture's interiority', ${ }^{17}$ and the diagram was the tool for a generative process which created new forms within the existing geometry. It relied on the same belief for him that architecture always has been something other than the real building itself or the real subject's relation to this building. Therefore, architecture could only exist in its pure form in a drawing, and the architectural object was more of a record of this process than the final result. ${ }^{18}$

Stefano Corbo, architecture theorist, has noted that in Eisenman's pursuit of a de-contaminated architecture free from representational properties, the justification of the process was therefore just as important as to define the formal properties of the architectural object. ${ }^{19}$ For Eisenman this led to a definition of the architectural object through the specific sequence of formal manipulations. Is architecture then ultimately a mere representation of such a process, so that in order to fully appreciate the object one had to know the way it was produced? Or was the process just a tool for the architect to produce or uncover a range of forms to choose from? The response may be in Eisenman's desire to go beyond the subject-object dichotomy, and to produce an architecture free from subjective judgement. ${ }^{20}$

\section{From Formal Essence to the Arbitrary}

In his early works, Eisenman's goal was to provide a system of order, relying on a deeper structure of formal-spatial relationships and to deny the production of what he deemed to be arbitrary forms. ${ }^{21}$ The arbitrary is here understood as an arrangement of shapes that lacks logical consistency or is based on a purely subjective judgement. Architecture defied this arbitrariness in its relation to a formal ideal or essential formal relationship, which in turn provided the premises for a claim to universality. Eisenman stated that:

'The principles in this discussion are rather to be thought of as being universally valid. Moreover, the contention will be that formal consideration are basic to all architecture regardless of style, and that 
these considerations derive from the formal essence of any architectural situation. It will provide a means of communication evolved from this absolute basis; a language that will communicate the nature of the formal essence of any architecture'. ${ }^{22}$

In this statement Eisenman proves his early position on the value of architecture. It is not aesthetic, because it is not based on a subjective response of pleasure or displeasure, but on the conceptual understanding of formal relationships, where the reference to a universal ideal or essence had to be apparent in the form. This "communication" of the formal essence could therefore establish a relationship between the architectural object and the subject having a response based on the perceptual experience of that object, and subsequently the possibility for a verdictive aesthetic judgement.

Later in his career, Eisenman abandoned the formal essence of architecture in favour of the arbitrary. Since architects throughout history had naturalised the indivisible link between the form and content, or the "architecture's iconicity and instrumentality", as the moral justification of any form, ${ }^{23}$ there could be no universal ideal, because of its relationship with the hegemony of meaning. For Eisenman, the conception and perception of architecture, how the object was seen and interpreted, were viewed as two distinct relationships between man and object. Dislocating these two relationships and separating them from each other was the new goal for an autonomous architecture. Only by admitting that there could be no intrinsic essence of architecture that provided an ultimate origin or truth could there be a possibility for new meanings. ${ }^{24}$ Since: 'To distinguish architecture from building requires an intentional act - a sign which suggests that a wall is doing something more than literal sheltering, supporting, enclosing; it must embody a significance which projects and sustains the idea of "wallness" beyond mere use, function or extrinsic allusion' ${ }^{25}$ This created the paradox for architecture to overcome the use and extrinsic signification, but without the use, function and extrinsic signification there would be no conditions which required this intentional act of overcoming. The only way to do this was by removing authority, removing the designer and allow the arbitrary. ${ }^{26}$ For Eisenman this arbitrariness was to be understood as a new fight for autonomy and criticality through a "dynamic process of difference" and not as a search for the ideal and universal. ${ }^{27}$ This meant canceling the subject completely, and does not at first glance allow for any aesthetic judgement. 


\section{Formalism against Meaning}

As we have seen architecture for Eisenman exists in-between the internal world of the human being and the physical world which we inhabit. ${ }^{28}$ It is the "diagram", "process", "communication of formal essence", "text", "dislocation", "presence" or "absence", or any other term Eisenman has used throughout his career. This in-between state has for Eisenman provided the possibility of an autonomous architecture without any extrinsic significance or meaning, ${ }^{29}$ or without any representational properties. If we think of this in-between state as the aesthetic, with aesthetic properties which the aesthetic judgment relies on, then I could propose a direct formalist position for Eisenman. This understanding of architecture is concerned with formal-spatial properties that can be perceived independent of extrinsic content, and since there is no clue in Eisenman's writing on the denial of this point, his hunt for autonomy is possible. This reliance on the architecture's intrinsic properties could therefore give primacy to a verdictive aesthetic judgement based on the apparent formal properties. Eisenman himself possibly hinted to this in a recent interview, where the most important criterion for any architectural project is that it "looks good" ${ }^{30}$ Could that be the beginning of the introduction of the subject in Eisenman's continuous work against extrinsic meaning in architecture? It certainly opens up for the possibility of an aesthetic formalist position in his work. 
See for instance Peter Eisenman, The Formal Basis of Modern Architecture (Baden: Lars Müller Publishing, 1963, Facsimile reprint, 2006), 55, and Peter Eisenman, "Processes of the Interstitial: Spacing and the Arbitrary Text" in Blurred Zones: Investigations of the Interstitial (New York: The Monacelli Press, 2002), 99.

Nick Zangwill, Metaphysics of Beauty (Ithaca: Cornell University Press, 2001), 24.

See Nick Zangwill, 'In his Critique of Judgement, Kant characterised what he called the "judgment of taste", by which he means what I have referred to verdictive judgments. In Kant's view, the most basic feature of judgments of taste is that they have subjective' universality in Zangwill, The Metaphysics of Beauty, 26. 
See Zangwill's analysis and arguments against the anti-formalist approach of Kendall Walton's Categories of Art, in Nick Zangwill, "In Defence of a Moderate Formalism," The Philosophical Quarterly Vol. 50, No. 201 (Oct. 2000): 476-493.

See Stefano Corbo, From Formalism to Weak Form (Farnham: Ashgate publishing Lt), 27.

See Eisenman, The Formal Basis of Modern Architecture, and Peter Eisenman, Diagram Diaries.

Eisenman, The Formal Basis of Modern Architecture, 87.

Ibid, 85.

Peter Eisenman, "Notes on a Conceptual Architecture," in Eisenman Inside Out: Selected Writings 1963-1988 (New Haven: Yale University Print, 2004, (1971)) 23.

Peter Eisenman "Cardboard architecture," in Eisenman Inside Out: Selected Writings 1963-1988 (New Haven: Yale University Print, 2004, (1972)), 39.

Stefano Corbo, From Formalism to Weak Form, 27.

See Peter Eisenman, Diagram Diaries (New York: Universe Publishing, 1999), 27.

See Eisenman's description of House VI 'House VI is not an object in traditional sense - that is, the result of a process - but more accurately a record of the process' in Cynthia Davidson (ed.) Tracing Eisenman, (London: Thames and Hudson, 2006), 66.

Stefano Corbo, From Formalism to Weak Form, 27.

See Eisenman, Diagram Diaries, 37 for the argument on the diagram as the "manifestation of architecture's interiority".

See Eisenman explaining an Inherent order from geometric reference and the properties of the form itself. 'Elaborated to encompass infinite variations and complexities (looks incomplete?). Systems deny only the arbitrary, the picturesque and the romantic: The subjective and personal interpretations of order' in Eisenman, The Formal Basis of Modern Architecture, 21.

Eisenman, The Formal Basis of Modern Architecture, 19.

Peter Eisenman, "Eisenman (and Company): Respond" Progressive Architecture, (Feb. 1995), 89.

Peter Eisenman, “Misreading Eisenman,” in Eisenman Inside Out: Selected Writings 1963-1988 (New Haven: Yale University Print, 2004, (1987)), 221.

Peter Eisenman, "Aspects of Modernism: Maison Dom-ino and the Self-referential Sign," in Eisenman Inside Out: Selected Writings 1963-1988 (New Haven: Yale University Print, 2004, (1980)) 120.

Eisenman, "Misreading Eisenman”, 215.

Peter Eisenman, “Autonomy and the Will to the Critical”, Assemblage, No. 41 (Apr. 2000), 90-91.

See Peter Eisenman, "Post/El Cards: A Reply to Jacques Derrida", Assemblage, No. 12 (Aug. 1990), 14-17, stating the same in-between position for architecture as between "sign and being" or between "absence and presence" as presentness, 16.

Eisenman, Peter. “Autonomy and the Will to the Critical,” Assemblage, No. 41 (Apr. 2000): 91.

See Eisenman's statement in Vladen Djokic and Petar Bojanic (ed.) Peter Eisenman: In Dialogue with Architects and Philosophers (Milan: Mimesis International, 2017) 'Every time a student presents something, and they give me this hullaballoo about process and all this, I say, you know, in the end, it either looks good or it don't. I say, I am sorry; this one doesn't look good.' 
Corbo, Stefano. From Formalism to Weak Form .Farnham: Ashgate publishing Lt.

Djokić, Vladan and Bojanić, Petar (ed.) Peter Eisenman: In Dialogue with Architects and Philosophers.

Milan: Mimesis International, 2017.

Davidson, Cynthia (ed.) Tracing Eisenman .London: Thames and Hudson, 2006.

Eisenman, Peter. The Formal Basis of Modern Architecture. Baden: Lars Müller Publishing (1963), Facsimile reprint, 2006.

Eisenman, Peter. "Notes on a Conceptual Architecture." In Eisenman Inside Out: Selected Writings 1963-1988, 11-27. New Haven: Yale University Print, (1971) 2004.

Eisenman, Peter. “Cardboard architecture.” In Eisenman Inside Out: Selected Writings 1963-1988, 28-39. New Haven: Yale University Print, (1972) 2004.

Eisenman, Peter. “Aspects of Modernism: Maison Dom-ino and the Self-referential Sign.” In Eisenman Inside Out: Selected Writings 1963-1988, 120. New Haven: Yale University Print, (1980) 2004.

Eisenman, Peter. "Misreading Eisenman." In Eisenman Inside Out: Selected Writings 1963-1988, 208-225. New Haven: Yale University Print, (1987), 2004.

Eisenman, Peter. "Post/El Cards: A Reply to Jacques Derrida.” Assemblage, No. 12 (Aug. 1990): 14-17.

Eisenman, Peter. "Eisenman (and Company): Respond." Progressive Architecture, (Feb. 1995): 8891.

Eisenman, Peter. Diagram Diaries. New York: Universe Publishing, 1999.

Eisenman, Peter. “Autonomy and the Will to the Critical." Assemblage, No. 41 (Apr. 2000): 90-91.

Eisenman, Peter. Blurred Zones: Investigations of the Interstitial, Eisenman Architects 1988-1998. New York: The Monacelli Press, 2003.

Zangwill, Nick. "In Defence of a Moderate Formalism.” The Philosophical Quarterly Vol. 50, No. 201 (Oct. 2000): 476-493.

Zangwill, Nick Metaphysics of Beauty. Ithaca: Cornell University Press, 2001. 


\section{ESTETIKA ODRŽIVOSTI: ARHITEKTURA KAPSULE U GRADU I U PRIRODI Peter Šenk}

Arhitektura najmanjih mesta za stanovanje je u poslednje vreme izuzetno popularna tema. Kada su najmanja mesta za stanovanje kompaktna, dobro opremljena, povezana na mrežu, strukturno, funkcionalno i vizuelno prepoznata kao jedna stvar, privremena i pokretna ili prenosiva, mogu se označiti kao arhitektura kapsule. Budući da su po svojoj prirodi privremena, ova najmanja mesta za stanovanje, skloništa, redizajnirane kontejnerske jedinice, posebne tehnološke konstrukcije, paraziti i druge manifestacije koncepta kapsula obuhvataju logiku tehnoloških objekata s izrazitim arhitektonskim izrazom. To je, istovremeno, manifestacija pravila održivog dizajna, održive arhitekture i održivosti uopšte. U ovom kontekstu slučaj najmanjih mesta za stanovanje pokazuje svoju razliku u odnosu na druge održive arhitektonske pristupe i estetike. Podredjuje uopšteno održive pristupe sa izraženim značajem lokaliteta unutar globalnih sila, obično se oslanjajući na kontekst - lokaciju, lokalnu kulturu i karakteristike životne sredine itd. Estetski režim trenutnih, promenljivih, kontekstualnih i autonomnih arhitektonskih struktura se može posmatrati kao estetika drugosti, koja ih povezuje sa nasledjem egzistencijalnih eksperimenata modernog pokreta, novim brutalizmom, radikalnim eksperimentima 1960-ih i drugim avangardnim i neoavangardnim praksama dvadesetog veka, ali čvrsto postavljenim u kontekstu individualizovane, neodredjene, raspršene i dvosmislene savremenosti.

KLJUČNE REČI: ESTETIKA PROMENE, KAPSULE, NAJMANJA MESTA ZA STANOVANJE, MINIMALAN TRAG, DRUGOST, ESTETIKA ODRŽIVOSTI

\section{ESTETIKA I KULTUROLOŠKI ASPEKTI BAUHAUSA: \\ KA NOVOJ KONCEPCIJI}

\section{Christiane Wagner}

Ovaj članak pokriva nove mogućnosti Bauhaus pogleda na svet: stvaranje novih oblika za prikazivanje ljudskih ideala kroz fokus na estetiku i tehnologiju, u kombinaciji sa Nimajerovim (Niemeyer) uticajem na arhitekturu i dizajn. Novi stilovi i oblici nastali su kao izdanci Bauhausa, prenoseći vrednosti svake kulture kroz izgradnju kolektivne „slike“ sveta. Bauhaus današnjice izražava industriju kulture, dijalektički razmatrajući inovaciju i primenjenu umetnost kao put od modernog dizajna industrijske revolucije do „eko dizajna“. U tom smislu, Bauhaus je još uvek značajan po svojoj ulozi, povezujući umetnost, tehnologiju i industriju. Inovacija kao dinamično odredjivanje trenutka, prisutna u svim epohama, se shvata kao moćna sila za održavanje tradicije. Pored hronološkog zapisa o uticaju Bauhausa, razmatraju se i značajni Nimajerovi projekti. Na kraju su prikazane dve perspektive ,raskola“ izmedju arhitekture i tehnologije. Prva perspektiva se odnosi na ljudsku sposobnost stvaranja modela u arhitektonskoj praksi za usvajanje kao konfiguraciju prostora. Druga se odnosi na evoluciju tehnologija koje vode do toga da zamišljeno postaje stvarnost kroz vreme, kako je to opisao Hegel (1823).

KLJUČNE REČI: IZRADA PO MERI, TEHNOLOŠKI RAZVOJ, PROSTOR-VREME, NOVI OBLICI

\section{KLASIČNA ARHITEKTURA U OKVIRU KANTOVSKE ESTETIKE: IZMEĐU LIOTARA I RANSIJERA}

\section{Helen Tatla}

Potencijal koji je svojstven klasičnoj arhitekturi da predstavlja glavni arhitektonski izraz zapadne kulture budući da je grčka antika nastala zbog svog dualnog karaktera: iako izvire iz iskonskog jedinstva stvari izraženih mitom i religijom u arhaičnim vremenima, ona dobija svoj završni oblik u petom veku p. n. e., kao simbol demokratije i harmonične artikulacije sveta na osnovu filozofskog mišljenja. 
Postavljajući avangardnu umetnost u sferu kantovske uzvišenosti, Žan Fransoa Liotar (JeanFrancois Lyotard) se fokusira na nemogućnost apsolutnog odnosa razuma i percepcije ili između razmišljanja i slike, u savremenosti. On smatra da se u slučajevima kada se to dogodi radjaju politička čudovišta. On povezuje postmoderne izraze klasicizma u arhitekturi sa Frojdovim „Tumačenjem snova“" i kantovskom lepotom.

Pristup Žaka Ransijera (Jacques Ranciere) kantovstvu na osnovu estetskog razmatranja modernosti suprotan je onome koji je predložio Liotar. Umesto uzvišenog, Ransijer povezuje lepo s pukotinom izmedju razmišljanja i percepcije. U tom pogledu, fragmenti prošlosti mogu da podstaknu kreativni proces u sadašnjosti.

Cilj ovog istraživanja je da doprinese dijalogu o obnovljenom pristupu ulozi klasicizma u arhitekturi danas.

KLJUČNE REČI: KLASIČNA ARHITEKTURA, KANT, LIOTAR, MODERNOST, POLITIKA, POSTMODERNOST, RANSIJER

\section{FLUIDNO STANJE ARHITEKTURE}

\section{Bojana Jerković-Babović}

Ovaj rad se bavi promenama u kriterijumima arhitektonske estetike, transformacija statičnih u dinamične vrednosti podjednako figurativnih i nefigurativnih aspekata savremene arhitekture i njenog konteksta. Fluidno stanje arhitekture odnosi se na prepoznavanje konstantne promenljivosti koja se manifestuje u relacijama arhitekture i savremenom kultuloroškog konteksta globalizacije. Savremeni kontekst dinamizuje perceptivna iskustva svakodnevnice, uslove života i načine prostornih aproprijacija. U skladu sa tim, novi fenomeni umreženosti koji se manifestuju na informacionim, komunikacionim i prostornim nivoima transformišu grad i arhitekturu u konstantne procese tokova, kojima se njihovi elementi dematerijalizuju u nove fluidne, promenljive karakteristike. Vredosti arhitektonske estetike istovremeno se transformišu ka afirmaciji dogadjaja i efekata naspram statične formale celine, od objektivnih do intersubjektivnih estetskih prostornih iskustava.

Ovaj rad se bazira na hipotezi da savremenu arhitekturu karakteriše gubitak singularnosti objekta u odnosu sa uslovima konteksta i asimilacija karaktera pojedinačnih elemenata u fluidni karakter celine. Na taj način, arhitektonske projektantske principe karakteriše disperzija disciplinarnih granica i granica unutrašnjosti i spoljašnjosti, hibridnost i gubitak tipoloških definicija. Ovaj rad prikazuje kako dematerijalizacija arhitektonskih vrednosti transformiše savremeni arhitektonski prostor u kompleksan dinamički sistem infrastrukture, tokova, događaja i efekata.

KLJUČNE REČI: ARHITEKTONSKA ESTETIKA, ARHITEKTONSKO PROJEKTOVANJE, ESTETSKO ISKUSTVO, DINAMIČKE VREDNOSTI, FLUIDNOST, GLOBALIZACIJA

\section{KINEMATOGRAFIJA I ARHITEKTURA: MODERNA PERCEPCIJA Sônia Campaner Miguel Ferrari}

Esej Valtera Benjamina (Walter Benjamin) o bioskopu objašnjava njegove prognostičke vrednosti. Dok je pisao ovaj članak, njegova kritika kapitalističkog načina produkcije pokazala je pravac u kojem kapitalizam napreduje: ka sve većoj eksploataciji proletarijata, ali i ka svom vlastitom padu. Nas zanimaju ove prognoze koje potvrdjuju transformaciju umetnosti i njene funkcije, a koja našu pažnju usmeravaju na gubitak transcedencije i opadanja aure umetničkog dela. One u isto vreme pokazuju mogućnosti kojima se potvrđuje kontinuitet umetnosti koja ima drugačiju ulogu i dislokacija aure. Oblik umetnosti koji je pogodan za ovakvo razmišljanje je kinematografija i paralela koju je filozof povukao izmedju kinematografije i arhitekture. Namera nam je da se osvrnemo na ovu paralelu i urbane intervencije kao umetničke oblike estetske modernosti: to 
jest, kao proizvode ove modernosti koji istovremeno ukazuju na način koji nam je dat i shvaćen. Takodje ćemo se osvrnuti i na indikacije bioskopa i pozorišta kao načina da se prevazidju telesne odrednice koje nam se nameću.

KLJUČNE REČI: ARHITEKTURA, BIOSKOP (KINEMATOGRAFIJA), MODERNA UMETNOST, MODERNA PERCEPCIJA, URBANIZAM

\section{AUTORSTVO I JEZIK U KNJIGAMA SAVREMENIH ARHITEKATA}

\section{Deniz Balık Lökçe}

Ovaj rad se bavi ispitivanjem teorijskih, grafičkih i materijalnih dimenzija savremene kulture štampe u arhitekturi sa fokusom na po jedno delo iz različitih evropskih praksi. Knjiga savremenog arhitekte posmatra se kao spekulativni i diskurzivni predmet dizajna. Mišel Fuko (Michel Foucault), posebno u svojim delima, Šta je autor? (1969) i Arheologija znanja (1972), kritikuje to da se prilikom izrade opusa jednog autora alternativni i neklasifikovani žanrovi izostavljaju iz domena, a tekstovi koji se vezuju za jedno ime pripadaju sistemu homogenosti, veze i recipročnog objašnjenja. Ipak, knjiga savremenog arhitekte proširuje granice žanrova tako što je sačinjena od nekonvencionalnih materijala, poput muzičkih nota, umetničkih fotografija, slika, tehničkih i naučnih dijagrama, zvaničnih izveštaja, gradjevinskih propisa, novinskih članaka i reklama, a takođe i od kombinacije tekstova i fotografija saradnika, partnera, klijenata i korisnika, a ne samo kao produkt jednog autora. Ovaj rad se bavi tumačenjem korišcenja različitih oblika grafičke naracije i spajanja nove terminologije i žargona kao doprinosa moći jezika i diskurzivnoj formaciji.

KLJUČNE REČI: ARHITEKTONSKI MEDIJI, ARHITEKTONSKA MONOGRAFIJA, KNJIGA, FUKO, ŽANR, KULTURA ŠTAMPE, AUTOR, TEKST

\section{ARHITEKTURA KAO TEKSTUALNI FENOMEN: APROPRIJACIUSKE ARHITEKTONSKE PRAKSE ALEKSANDRA BRODSKOG Boško Drobnjak}

Tekst analizira arhitekturu nastalu aproprijacijom postojećih materijala fokusirajući se na strategije intertekstualnosti. Rad zastupa tezu da značenje arhitektonskog objekta ne proizlazi iz njega samog ili njegovih poetskih koncepata, već iz njegovih odnosa sa drugim arhitektonskim objektima, drugim umetničkim delima kao tekstovima, kulturalnim tekstovima i svakodnevnim životnim praksama. Cilj rada jeste da se pokažu različiti teorijski problemi teorije arhitekture i umetnosti koji kao mreža uodnošenih tekstova kulture okružuju arhitektonsku produkciju Aleksandra Brodskog (Alexander Brodsky). Za metod rada je karakteristično operisanje sa različitim i raznorodnim teorijskim konceptima, uzimajući odabrane studije slučaja (Votka paviljon i Rotunda) arhitekture Brodskog u okviru koje je rad koncipiran kao interdisciplinarna studija.

KLJUČNE REČI: ALEKSANDAR BRODSKI, APROPRIJACIJA, SVET UMETNOSTI, EKSPERIMENTALNA ARHITEKTURA, READY-MADE, TEKST

\section{PITER AJZENMAN I MOGUĆNOST ESTETSKOG FORMALIZMA \\ Amund M. Rolfsen}

Formalna razmatranja predstavljaju srž aspekta rada Piter Ajzenmana (Peter Eisenman). Može se tvrditi da su ona jedina dosledna tema njegovog rada, i zasnivaju se na konceptu da je arhitektura posredovanje izmedju otelovljenog unutrašnjeg sveta ljudskih bića i spoljnog fizičkog sveta koji naseljavamo. Ajzenman tako daje „konceptualnu“, a ne percepcijsku osnovu, pri čemu su univerzalni formalni odnosi važniji od čulnih aspekata. Na taj način arhitektura ostaje kao 
sintaktička radnja zasnovana na razumu i logici, s očiglednim formalnim odnosima kao glavnim opravdanjem. Razumevanje i razvoj inherentnog formalnog jezika postaje glavni cilj takvog pristupa, a značenje se zanemaruje u svom spoljašnjem karakteru s pozivanjima na društvene, istorijske ili druge reprezentativne osobine.

U ovom radu raspravlja se o Ajzenmanovim pogledima na arhitektonski formalizam kroz sferu estetike. Budući da je tokom karijere zanemario estetska razmatranja, posebno lepotu, korisno je istražiti i ispitati njegov stav o svojstvima arhitekture kao načinu da opravda svoje tvrdnje o prednosti formalnosti. Data analiza zasniva se na formalističkim teorijama Nika Zangvila (Nick Zangwill) i na taj način prednost je data formalno-prostornim svojstvima arhitektonskog objekta onako kako o njima sudi osoba. To bi moglo da vrati rasprave o formalističkoj estetici u arhitektonsku teoriju i da donošenje suda o kvalitetu arhitekture bude formalno pitanje.

KLJUČNE REČI: ESTETSKA SVOJSTVA, FORMALIZAM, PITER AJZENMAN, UNUTRAŠNJA I SPOLJNA SVOJSTVA, NIK ZANGVIL

\section{SMRT ESTETIKE U ARHITEKTONSKOM OBRAZOVANJU? \\ MOGUĆNOSTI SAVREMENE PEDAGOGIJE}

\section{Renata Jadrešin Milić, Catherine Mitchell}

Značaj estetike u arhitekturi ima dugu istoriju. Iako pojam nije bio prisutan u pisanim traktatima pre 1735. godine i Baumgartena (Alexander Gottlieb Baumgarten), mesto estetike se može prepoznati kroz arhitektonsku teoriju i filozofiju još od vremena Vitruvija. Razvijanje estetskog senzibiliteta smatrano je ključnim za arhitektu, a proučavanje arhitekture shvaćeno je kroz tri Vitruvijeva koncepta (utlitas, firmitas, venustas) od kojih je venustas direktno povezan sa estetikom. Ovaj rad je odgovor na aktuelne diskusije izmedju arhitekata, arhitektonskih pedagoga i studenata arhitekture o ulozi estetike u arhitektonskom obrazovanju i stručnoj praksi danas. Prvobitno je inspirisan pitanjima postavljenim na godišnjim konferencijama SAH u 2017. i 2018. godini, o ulozi arhitektonske istorije u arhitektonskom projektovanju i praksi danas, a u vezi sa tim, i pitanjima o mestu estetike u arhitektonskom obrazovanju. Ovaj rad daje detaljan pregled ključnih pedagoških intervencija napravljenih u jednom programu studija arhitekture, koje mogu biti od koristi edukatorima zainteresovanim da održe mesto estetike u savremenom arhitektonskom obrazovanju. To sugeriše da estetika može i dalje da ima ključnu ulogu u arhitektonskom kurikulumu, fokusirajući sa na rešavanje projektantskih problema i istovremeno odgovarajući na savremene obrazovne zahteve za akreditaciju.

KLJUČNE REČI: ESTETIKA, ARHITEKTONSKO OBRAZOVANJE, BUDUĆE VEŠTINE ZA ZAPOŠLJAVANJE, KRITERIJUMI ZA AKREDITACIJU 